\title{
Por uma sociologia crítica da ciência'
}

IAN JARUE*

JOSEPH AGASSI

\section{Resumo}

Neste artigo crítico e construtivo, defendemos que a Sociologia da Ciência, como está estabelecida, é distorcida por uma suposta filosofia idealista que estimula uma atitude acrítica em relação ao que se supõe serem fatos. Propomos uma sociologia crítica da ciência que faz a distinção entre ciência, ciência aplicada e tecnologia; enfoca a falibilidade da ciência e da sociologia da ciência que desconstrói toda pretensão de autoridade. Construtivamente, esboçamos os elementos de uma sociologia da ciência que envolve as formas elementares da vida científica, bem como a ciência "normal" contemporânea, burocratizada e militarizada.

Palavras-chave: Merton. Sociologia da ciência. Programa forte. Autoridade. Instituições. Gieryn. Linguagem. Conhecimento objetivo.

1 Tradução de Marcelo Otto Severo

* Professor BSc, PhD(University of London) York University - Philosophy Department - Toronto. Managing Editor, Philosophy of the Social Sciences, a scholarly journal.

** Emeritus Professor, Tel-Aviv University - Philosophy Department 


\section{Nossas Advertências Filosóficas}

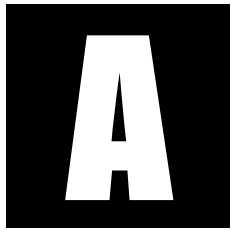

pesar de o título deste trabalho sugerir uma varredura, o que implica em um estudo descritivo, ou mesmo etnográfico, da ciência, seu objetivo é mais modesto. O que estamos oferecendo aqui é apenas um esboço, livre de três falhas: três pressupostos e conclusões filosóficas que a sociologia da ciência tem como certos. O primeiro pressuposto diz respeito à autoridade da ciência na ordem social contemporânea. Essa autoridade é explicada como sendo uma construção social; portanto, é nossa obrigação aceitá-la. Concordamos que cabe à sociologia da ciência explicar a autoridade da ciência, mas devemos tomar cuidado para não aceitar essa autoridade de forma acrítica. O segundo pressuposto é o de que não há razão social para distinguir ciência de tecnologia. Pelo contrário, defendemos que, apesar de estarem misturadas na mente do público e dos oficiais, a sociologia (crítica) da ciência deve apresentá-las como diferentes em termos de objetivos, organização social e estrutura institucional. O terceiro pressuposto é o de que os fatores socioeconômicos são suficientes para explicar o crescimento do conhecimento científico. Admitimos que a investigação não é tão imune à influência desses fatores quanto imaginavam os pensadores clássicos do Movimento Iluminista, mas eles não são suficientes para explicar o funcionamento das instituições sociais da ciência.

Antes de analisarmos mais profundamente cada um desses pressupostos, precisamos esclarecer a natureza das nossas objeções, provenientes de uma visão filosófica da ciência, que pode ser traduzida como uma empresa crítica e autocrítica. Mas, antes disso, queremos vincular nossa busca por falhas ao título do trabalho.

Se vamos erradicar da sociologia da ciência essas suposições filosóficas (perniciosas) sobre ciência, não basta apresentar um argumento filo- 
sófico contrário. Os adeptos da sociologia da ciência podem alegar que estão descrevendo a ordem social, por mais racional ou perversa que seja a filosofia que está por trás dela. Concordamos em parte: nós admitimos que, pelo menos no caso da autoproclamada autoridade científica e no da fusão entre ciência e tecnologia, a mente do público está confusa e esta confusão se reflete nas características da sociedade que dependem (ou pelo menos resultam) da visão filosófica da ciência que vamos contestar neste trabalho. Mas o quadro que estamos descrevendo é misto: as evidências indicam que o público, às vezes, admite que a ciência e os cientistas podem falhar; que o público, às vezes, admite que as mais recentes revelações da ciência não são a última palavra sobre o assunto. Talvez o público até admita, às vezes, que a ciência e a tecnologia são completamente diferentes, como quando prefere financiar tecnologia e ciência aplicada, no lugar da ciência pura.

Para tornar o nosso argumento mais permanente, precisamos traçar as possibilidades de uma sociologia da ciência que enfatiza o lado especulativo da ciência e, com isso, ressalta a diferença que existe entre a ciência e a tecnologia. Para tanto, buscamos uma sociologia geral da ciência, que admite o ceticismo social quanto à autoridade da ciência e atribui autoridade social à tecnologia baseada na ciência. No que diz respeito ao progresso da ciência, os defensores do Programa Forte alegam que podem explicá-lo através de fatores socioeconômicos. Rejeitamos essa afirmação: acreditamos que é reducionista e que está em desacordo com idéias amplamente difundidas sobre a criatividade. Isso, em si, não representa uma objeção irrefutável, mas é um bom ponto de partida, e nós o adotamos neste trabalho.

Vamos agora discorrer um pouco sobre os três pressupostos filosóficos mencionados anteriormente, que permeiam a sociologia da ciência. O problema de atribuir autoridade à ciência é simples: é um fato social, 
é verdade, mas é um fato que incorpora um erro fundamental. Este erro pode ser traduzido como uma falsa descrição da ciência. Uma descrição mais crítica revelaria que a ciência não tem autoridade alguma e não requer fé. É uma aventura intelectual que levanta algumas idéias férteis, surpreendentes. Essas idéias, no entanto, não trazem consigo nenhuma autoridade; atribuir-lhes autoridade, ou pior, atribuir essa autoridade a alguns cientistas (como "especialistas"), só pode ser resultado de um grave equívoco. ${ }^{2} \mathrm{O}$ status de prestígio que o público atribui a ciência é, obviamente, uma construção social, mas a autoridade atribuída à ciência também é uma construção social, como a autoridade política, religiosa, burocrática e de outros subsistemas. Nenhuma delas precisa da aprovação do sociólogo. Os adeptos da sociologia da ciência podem estar receosos de que, se negarem essa aprovação, estão prejudicando o status descrito. ${ }^{3}$ Ou podem alegar que a autoridade científica está entre os fatos sociais com os quais eles trabalham. (Chamar alguma coisa de fato é o mesmo que aprová-la tacitamente.) Pretendemos contestar tudo isso e defender o oposto: que a desconstrução da autoproclamada autoridade da ciência seria um emprego melhor para os sociólogos da ciência, e que, dessa forma, eles estariam trabalhando para o seu crescimento e não, para prejudicar o seu status social. Sua alegação de que a autoridade da ciência é

2 Em nossos trabalhos, temos argumentado contra a fusão de ciência e fé, e contra o "culto da ciência". A fé é um assunto particular; uma sociedade livre não precisa que acreditem nisso ou naquilo. É possível aprovar um projeto científico sem acreditar em suas descobertas. É a ênfase na fé que atrai acusações de que a ciência é um substituto para a religião. É verdade que algumas pessoas pensam dessa forma; elas simplesmente ignoram o quanto é diferente o tipo de esforço cognitivo que é a ciência, incluindo sua sociologia diferente. Desde a revolução científica, seus defensores têm negado que a ciência impõe a fé em sua doutrina. É por causa da sociologia diferente que alguns cientistas podem realizar pesquisas bem-sucedidas e, ao mesmo tempo, manter crenças religiosas antiquadas.

3 Na medida em que as carreiras e o poder dos sociólogos da ciência, na academia, dependem dos membros um comitê que, como cientistas profissionais, vêem como sua tarefa manter a autoridade da ciência, o trabalho dos sociólogos da ciência é tão suspeito como o de qualquer outro exercício de relações públicas. 
uma construção social, e de que a ciência é também uma construção social, pode ser transcendentalmente reveladora, mas, uma vez que não aceita nada além do social, torna-se um esforço de prestidigitação: uma revelação que não revela nada. Diz-se que a autoridade reivindicada pela ciência na sociedade, resulta de uma suposta autoridade intelectual (a saber, "epistêmica"). Em nossa opinião, a ciência não tem autoridade intelectual porque não existe tal coisa. Os adeptos da sociologia da ciência deveriam ver a atribuição de autoridade à ciência como um mito a ser explicado ou como uma instituição social a ser descrita, ou ambos, mas, neste caso, separadamente - sem submissão intelectual. Não é prudente descartar, a priori, a possibilidade óbvia - para não dizer o fato óbvio - de que é do interesse de alguns defensores da ciência, incluindo alguns cientistas, simular uma autoridade (que não existe). Principalmente, mas não somente no caso dos pressupostos que queremos contestar, só a possibilidade dessa simulação já é o bastante para abrir espaço para nossa investigação, uma vez que os esforços que foram feitos para negar o fato, a priori, não foram sérios.

Certamente os adeptos da sociologia da ciência poderiam argumentar que eles desconstroem mitos e pretensões científicas em seus estudos sobre a vida de laboratório e práticas de investigação em curso. Talvez, mas reduzir a ciência a práticas rotineiras de trabalho como estudos sobre piso de fábrica, é negligenciar outro ponto filosófico. Podemos distinguir dois tipos de trabalho científico: o esforço para refutar velhas idéias e o esforço para criar e testar novas idéias. Idéias são produtos abstratos e intangíveis, cujo valor é definido no mercado intelectual, onde outros podem buscá-las, localizá-las e examiná-las. Podemos também identificar três submercados intelectuais onde ocorre essa busca, localização e análise. Existe o mercado inicial, onde as idéias têm circulação restrita, na forma de brainstormings, propostas de pesquisa, preprints. (Pense no relato de Watson, de como ele e Crick pediram a Bragg, de Cavendish, 
para investir recursos em suas idéias.) Este primeiro mercado é pequeno e reservado. O segundo mercado é o mercado futuro, onde as idéias que tiveram grande impacto no mercado inicial podem continuar a brilhar ou desaparecer; enquanto aquelas que tiveram pouco ou nenhum impacto podem continuar assim, ou começar a brilhar. (Pense em short communication to Nature, onde Crick e Watson apresentaram a estrutura do DNA, e nas dicas sobre as possíveis ramificações de sua descoberta para futuras pesquisas. Depois, pense no crescimento exponencial de citações.) O terceiro mercado é o público em geral. Um exemplo deste mercado seria a revolução no pensamento médico, a ascensão da teoria dos germes, seu refinamento em sistêmica, bacteriana, viral, auto-imune, e outras variações que passaram a ser conhecidas pelo público. Elas se tornaram parte do programa sobre doenças ensinado nas escolas e influenciaram práticas populares de higiene, nutrição e imunização. (Pense na conquista do Prêmio Nobel, por Watson, Crick e Wilkins, e nas carreiras estelares dos três, incluindo a popularização da ciência.)

Nenhum dos três mercados atribui autoridade a produtos abstratos e intangíveis, como fazem os mercados com idéias religiosas ou jurídicas, através de mecanismos sociais familiares. Na verdade, a única autoridade que faz sentido (filosófico) reivindicar para a ciência é a perspectiva que propõe a investigação racional de problemas que deveriam receber uma atenção mais séria do que opiniões inconseqüentes e não-testadas - mas esse cuidado é muito limitado se exclui idéias arrojadas só porque são arrojadas. (Pense nos critérios de Niels Bohr para descartar idéias que não eram suficientemente arrojadas).

Em nossa opinião, parte da confusão quanto à autoridade vem da fusão entre ciência e tecnologia na mente do público - e da sociologia também. Nós não somos puristas: para fins de discussão, a diferença entre ciência e tecnologia não é importante, e pode até ser negligenciada. Mas, 
quando estamos falando de autoridade, a diferença é muito importante. A tecnologia possui autoridade - não intelectual, mas institucional. A sociedade atribui autoridade à tecnologia e, com isso, estabelece as normas que a tecnologia precisa seguir para que possa reivindicar essa autoridade. Essas normas, em sua maioria, são legais e semilegais, ou seja, são garantidas pelo poder do Estado e dos seus órgãos. (Pense nos códigos de construção locais, nas melhores práticas de engenharia e arquitetura de edifícios, pontes, túneis; pense nos testes que precedem o licenciamento de medicamentos; nos requisitos para a regularização de profissões; nos certificados de aeronavegabilidade.)

Diferentemente dos cientistas, os tecnólogos são legalmente responsáveis pelos seus produtos. ${ }^{4} \mathrm{Na}$ ciência pura não existe nada igual. Os cosmólogos não são, de forma alguma, socialmente responsáveis pelo fato de que, em seus modelos padrões, a vida humana é um pequeno e insignificante episódio da origem e evolução do universo. Pode-se argumentar que essas idéias, ou outras similares, são desmoralizantes e têm efeitos nocivos; mesmo assim, não há ninguém para culpar. Alguns cientistas podem, naturalmente, advertir, demonstrar compaixão, tentar abafar as implicações, e assim por diante; mas isso nada tem a ver com a sua responsabilidade científica. Todos os cientistas são cidadãos, mas eles querem ter a liberdade de desconsiderar os desejos dos seus concidadãos, sob a alegação de que estes estão atrapalhando a busca da ciência - mas, dentro dos limites da lei. (Pense na Convenção de Helsinque). Cidadãos problemáticos podem ser cientistas não-problemáticos. (Pense em Kurt Gödel e John Nash).

4 Às vezes, os sociólogos referem-se à ciência como uma profissão. Nossa visão é mais rigorosa: uma profissão é um monopólio organizado e legalmente definido. Como qualquer trabalhador, um cientista pode agir com profissionalismo, mesmo que não seja membro de uma profissão. 
A linha que separa a ciência da tecnologia tem que ser investigada porque os objetivos, as estruturas sociais e a ética dos tecnólogos são muito diferentes daqueles da comunidade de investigação livre e racional, que é o tipo ideal de ciência. A confusão entre as duas pode ser deliberada, como quando a bomba atômica ou a cura do câncer são alardeadas, a fim de se obter dinheiro para pesquisas ou quando as autoridades militares ostentam dinheiro, a fim de obter os serviços de cientistas. A sociedade como um todo deveria assumir a responsabilidade pela criação de um sistema de incentivos. Os adeptos da sociologia da ciência podem até criar modelos para impor esses incentivos à ciência, como se não houvesse alternativa, mas cabe aos tecnólogos sociais examinarem esses modelos antes de implementá-los, buscar a melhor maneira de testá-los e tentar melhorá-los.

A cooperação profunda entre a ciência aplicada e a ciência pura é, em parte, responsável pela confusão que existe entre as duas. A ciência aplicada compreende os esforços para colocar a ciência pura em uso prático, ou então, para desenvolver a ciência pura, de forma que possa servir a esse fim. Esta última atividade é conhecida como ciência básica. A medicina é uma ciência aplicada que se baseia na ciência pura da biologia, bioquímica, química, mecânica quântica, e até mesmo, da mecânica clássica (para diagnosticar lesões ósseas, por exemplo). A tecnologia da medicina envolve a produção de fármacos, procedimentos cirúrgicos e dietas e talvez envolva também projetos de clínicas e de sistemas especializados (softwares), uma vez que estes fazem com que a ciência aplicada trabalhe a favor do paciente. É importante ressaltar que determinadas fórmulas sociais, e alguns tipos específicos de arranjos sociais, precedem tanto a possibilidade de aplicar a ciência quanto a de criar novas tecnologias. A medicina é, antes de tudo, uma tecnologia social: um conjunto de arranjos sociais que forma especialistas em doenças humanas; enquanto convence a população de que a forma de lidar com o seu sofrimento é através de encontros clínicos 
com esses especialistas e de uma "apresentação" adequada. Os tecnólogos sociais criam formas de aplicar a tecnologia médica dentro dos arranjos sociais, incluindo a burocracia e a industrialização; isso lhes permite oferecer uma vasta gama de tecnologias médicas, testadas e acessíveis, aos profissionais da saúde. A forma como tudo isso interage com o sistema de segurosaúde é extremamente complexa, requer muito cuidado e planejamento, e acompanhamento e revisão permanentes.

A sociologia clássica do conhecimento, da qual se originaram os estudos sociais da ciência como estão estabelecidos, não pretende explicar o crescimento do conhecimento científico através de variáveis socioeconômicas. Para saber por que, basta aplicar a teoria que diz: "o conhecimento científico é resultado de fatores socioeconômicos". Chame isso de S. Temos, então, a alegação de que S é o resultado de alguns fatores socioeconômicos. Será que esta afirmação é verdadeira? Se for, então alguns fatores socioeconômicos levam à verdade! E se descobrirmos quais são esses fatores? Produzi-los vai gerar ciência. Isso não pode ser verdade. Nota: isso não impede que a recepção de idéias científicas no mercado futuro e no mercado público seja suscetível à análise socioeconômica. Qualquer biólogo pode ver que a descoberta do DNA, por Crick e Watson, abriu imensas possibilidades para novas pesquisas em diversas áreas correlacionadas. Algumas organizações financeiras se mostraram receptivas e investiram dinheiro em projetos, mas esse é um assunto que diz respeito à recepção de inovações, que não deve ser confundida com as próprias inovações.

A inovação, em nossa opinião, é uma realização intelectual que pode ser explicada, ainda que parcialmente, pelas pressões intelectuais que os pensadores enfrentam, por seus problemas e situações-problema. A compreensão desses problemas e situações-problema lança luz sobre descobertas bem-sucedidas e avanços que não foram vistos como tal quando surgiram. Além disso, torna-se óbvio que todas as explicações propostas pelo Programa Forte para as mudanças em conceitos científicos não explicam as idéias e o seu surgimento, mas a recepção dessas idéias. 
O progresso científico é confundido com a recepção científica. Isso até faz sentido, uma vez que as idéias ignoradas pelo público esclarecido são esquecidas. Mas está errado. Há contra-exemplos para os dois casos. Uma boa recepção não é prova de que uma idéia não é um fracasso; da mesma forma, o descarte de uma idéia, que a primeira vista parece um fracasso, não é prova de que esta não pode vir a ser reconhecida como um sucesso. Um exemplo do primeiro tipo seria a teoria psicossomática das úlceras gástricas. Um exemplo do segundo tipo seria a teoria da deriva continental, de Wegener. ${ }^{5}$ Como resposta aos dois casos, os sociólogos da ciência poderiam alegar que o consenso muda: ele se agrupa por um tempo, se dissolve, e então se reagrupa em outro lugar. Esta resposta não pode ser questionada. Este agrupamento, dispersão e reagrupamento, uma vez que se trata de um processo social, está sujeito à explicação socioeconômica - pelo menos até certo ponto. Geógrafos e geólogos explicam por que Wegener foi ridicularizado: costumam dizer que havia uma falha na teoria quando esta apareceu pela primeira vez, o mecanismo. ${ }^{6}$ Que forças poderiam estar movendo essas enormes placas continentais? Só depois que surgiram novas idéias sobre correntes convectivas de calor sob a superfície da Terra, pareceu viável aceitar a deriva continental e,

5 Ver o estudo de Naomi Oreskes (1999), e os comentários de Rachel Laudan em sua resenha (2000). Oreskes também co-editou uma antologia das memórias daqueles que participaram da revolução científica no campo das ciências da terra (Oreskes, 2001). Nos dois volumes, ela recorre à linguagem da fé (ver nota 1, acima). Em nossa opinião, isso é inquestionável, e pode ser substituída, em todos os casos, pela linguagem das "idéias", sem perdas. Seu aforismo "ciência não é sobre fé, mas como a fé é formulada", por exemplo, pode ser traduzido como "ciência não é sobre idéias, mas como as idéias são formuladas" (Oreskes, 1999:6). Essa tradução é bastante útil e revela uma falsa dicotomia: a ciência é sobre as idéias e as suas formulações. Não é sobre crenças. As idéias podem ser formuladas e promovidas sem estarem aprovadas, e menos ainda acreditadas.

6 Oreskes (1999) mostra-se bastante convincente ao afirmar que isso veio depois; diversos mecanismos foram apresentados. Sua explicação é diferente: a resistência se deve à antipatia indutivista do modelo teórico de ciência. Oreskes argumenta também que os geofísicos indutivistas americanos operavam com várias "hipóteses de trabalho". Não fica claro se ela percebe que o seu modelo dessa ciência é um contra-exemplo fascinante da afirmação de Kuhn de que a verdadeira ciência exige consenso sobre um paradigma. A beleza está no fato de a geofísica ser uma "ciência dura" (hard science). 
então, recorrer a dados ecológicos independentes para testá-la; no que se revelou uma ferramenta poderosa para explicar a difusão de espécies animais e vegetais de todo tipo. Dessa forma, as idéias de Wegener passaram a ser discutidas; e, de fato, foram amplamente discutidas e com seriedade. Há fatores socioeconômicos em jogo, certamente, a comunicação em especial; mas os aspectos intelectuais são a melhor parte da história. Sendo assim, alegar caprichos do consenso, mesmo que seja verdade, não responde às críticas: não é suficiente para evitar os ataques que acusam a sociologia da ciência de ignorar a carne para ficar com o molho.

A carne do debate é intelectual: as deficiências de uma teoria explicam a negligência para com a mesma; e são os suplementos e modificações que explicam a mudança para uma recepção positiva. Os adeptos da sociologia da ciência vão além. O que eles observam, ouvem dos cientistas, escrevem, enfim, tudo isso aponta para uma história de incerteza e disputa, uma história de acumulação de argumentos e provas, e de sugestões que variam conforme as conclusões observadas. Esta atividade Ihes parece uma introdução à Debate e Retórica. Um curso de Debate e Retórica normalmente ensina que as disputas são resolvidas pelo voto, de juízes em um concurso de debates, dos membros presentes em uma sociedade de debates (como a Oxford Union, por exemplo). Às vezes, debates dos dois tipos giram em torno de questões onde realmente existe alguma coisa em jogo (outras vezes é apenas ironia). Da mesma forma, argumentam os adeptos da sociologia da ciência, os cientistas usam de retórica e persuasão toda vez que tentam forjar um novo consenso, que são construções sociais como qualquer outra. O resultado é uma situação desnecessariamente confusa. Por que os cientistas não descrevem o caso dessa forma? Será que é porque eles não são sociólogos e não sabem como abordá-lo e descrevê-lo sociologicamente? Ou é porque, apesar de estarem cientes de que as características se assemelham as de um 
concurso de debates, eles consideram a questão subjacente e o conteúdo dos argumentos extremamente importantes? Mesmo cientistas sociologicamente conscientes, como Michael Polanyi, Thomas S. Kuhn, e Paul $\mathrm{K}$. Feyerabend, não reduzem as glórias da ciência a práticas mundanas de negociação, retórica e debate, ou a determinantes socioeconômicos. Essas são práticas consagradas na comunidade, certamente, assim como em outras instituições sociais. A questão é: qual é o ponto principal, para a ciência? É o consenso? É o sucesso com o público? É o dinheiro para pesquisas? São medalhas e prêmios? São citações? Nenhuma dessas opções oferece uma explicação satisfatória. O consenso é sobre uma ou outra coisa ser o caso; o dinheiro é dado em promessa; as medalhas e os prêmios são dados por realizações; as citações referem-se a idéias. Qual é o referente destas expressões: “o caso", "promessa", "realizações", "idéias"? Se os adeptos da sociologia da ciência disserem que se trata de autovalidação, então o argumento é circular. O sociólogo pode estar inclinado a ceder e concordar, mas existe outra opção?

Não é preciso discutir a diferença entre a ciência e a magia para saber que a sociologia da ciência é pró-ciência e antimagia. Mesmo assim, é capaz de distinguir a magia verdadeira da falsa - ao referir-se a magia como uma instituição social. O mesmo não ocorre com a ciência, uma vez que a veracidade da ciência é muito mais uma questão de provas objetivas do que ser uma instituição social. Para ser mais preciso, a testabilidade da ciência é a sua principal característica institucional. Em nossa opinião, a sociologia da ciência empenha-se em ignorar esse fato, e encara a ciência como uma forma eficaz de magia.

A razão para essa omissão por parte da sociologia da ciência é simples. A questão, na agenda da sociologia da ciência, é filosófica, mas os sociólogos se mostram céticos em relação aos filósofos e cientistas que argumentam que há uma medida que é especulativa, incerta e não-mono- 
tônica com o consenso social dos cientistas (e menos ainda com o do público em geral). Essa medida é conhecida como o fato, o caso, a verdade, a realidade, Mãe Natureza. ${ }^{7}$ Todas as tentativas de se obter e apresentar resultados científicos começam com esforços conjuntos e terminam com afirmações expressas em linguagem, e estas são necessariamente sociais, de acordo com os sociólogos da ciência. E - eles concluem - os resultados científicos devem ser vistos como construções sociais, necessariamente. Esta inferência não é válida: o esforço social não faz de alguma coisa algo social. Os esforços sociais têm um objetivo, que é socialmente definido, mas, seja ele qual for, não precisa ser uma entidade social e nada mais. A democracia, os museus e as universidades são entidades sociais; os cidadãos e as obras de arte e da ciência estão além disso.

Segundo Ernest Gellner (1973:17 e outros lugares, conforme Russell), os argumentos que sustentam todas as formas de idealismo metafísico geralmente repousam sobre a doutrina das relações internas. De acordo com essa doutrina, as relações são "internas" às coisas, ou seja, as relações [entre as coisas] são assimiladas pelas propriedades [das coisas]. Ele sugere também que, ao considerar a sociedade, essa doutrina torna-se bastante tentadora. Sendo assim, considerar a sociedade torna o idealismo bastante tentador. O idealismo do Programa Forte, na sociologia da ciência, tem duas fontes. Uma delas é a idéia circular de que toda atividade humana é uma atividade social e, portanto, só existem atividades sociais. A outra é o idealismo lingüístico de Wittgenstein, que deu a entender que, se a linguagem é uma atividade social, qualquer coisa expressa em linguagem é moldada, limitada e explicada pela linguagem e forma de vida. (Com o

7 Como sempre, Oreskes é clara e contundente: "Os cientistas estão interessados na verdade. Eles querem saber como o mundo realmente é, e eles querem usar esse conhecimento para fazer coisas no mundo." (Oreskes, 1999:3). 
termo "Lebensform", ele parece querer dizer forma de vida social, ou seja, a sociedade, simplesmente. Dessa forma, ele conseguiu contrabandear muito da metafísica, com a ajuda de um termo técnico obscuro.) Temos, então, uma versão especial do antropomorfismo que considera a ciência universal uma ilusão, uma vez que toda a ciência, desde as suas medidas fundamentais até a sua linguagem, é moldada sob o ponto de vista do Homo sapiens, e não pode ser mapeada para observadores não-humanos ou mesmo ser inteligível para eles.

Queremos saber se é possível criar uma sociologia geral da ciência que não endossa a autoridade da ciência, pelo contrário, desconstrói; uma sociologia geral da ciência que diferencia ciência de tecnologia, e que circunscreve um domínio autônomo para a realização intelectual como tal. Não pretendemos esconder o nosso sistema de valores: nós valorizamos as idéias e acreditamos que elas têm uma existência autônoma. Isso inclui idéias sociológicas de antepassados ilustres: Marx, Durkheim, Simmel, Weber, Evans-Pritchard, Popper, Gellner. Os sociólogos da ciência confundem a comunidade de aprendizagem com as diversas instituições da qual ela faz parte, instituições essas que mudam mais rápido do que a comunidade. Quando Popper escreveu sobre o conhecimento objetivo como uma instituição, ele surpreendeu e incomodou a muitos, ao evitar essa fusão equivocada das instituições com o todo a que servem e constituem. O conhecimento objetivo é uma parte da comunidade de aprendizagem, e também não deve ser confundido com as instituições onde está inserido, tais como museus, bibliotecas e a internet.

\section{Nossos alvos}

Até agora, deixamos de lado a especificação da sociologia da ciência. Embora leitores (ocasionais) atentos da sua literatura, nenhum de nós poderia 
reivindicar o status de especialista no assunto. Podemos agora ser um pouco mais específicos. Para isso, contamos com um artigo de pesquisa de Thomas F. Gieryn, "Science, Sociology of", publicado na International Encyclopedia of the Social and Behavioral Sciences, da editora Elsevier (2001), o qual nos parece abrangente e, até certo ponto, crítico. ${ }^{8}$ Gieryn é um intelectual da Universidade de Indiana. Ele divide a sociologia da ciência em três seções principais (mais uma pré-história no começo e um futuro incerto no final). A primeira seção é mertoniana: enfoca a ciência como uma forma de organização social. A segunda trata dos processos que constituem a ciência. E a terceira está relacionada com a ciência como autoridade, ou, mais precisamente, com os cientistas como detentores de autoridade cognitiva.

Gieryn apresenta uma visão parcial da sociologia da ciência. Por um lado, ele reitera a discrepância que existe entre as pretensões de universalismo e comunismo (Merton); e pelo outro a organização hierárquica da ciência, o princípio da vantagem cumulativa, o sexismo sistêmico e sistemático, e uma total falta de democracia. Essas observações e críticas são bem-vindas, mas temos algumas ressalvas quanto à democracia, uma vez que a crítica nunca foi censurada na ciência como foi nos regimes políticos não-democráticos. ${ }^{9}$ Na verdade, se fôssemos resumir a nossa reclamação, diríamos que a sociologia da ciência dá muito crédito a afirmações falsas e tendenciosas sobre a ciência e não se mostra suficientemente crítica (e, portanto, não muito científica). Nossa meta é uma sociologia da ciência suficientemente crítica que começa pela separação do joio e do trigo. A ciência é de suprema importância como um esforço humano. No entanto, está nas mãos de pessoas que nem sempre estão comprometidas com essa

8 Nós temos algumas críticas sobre o artigo como pesquisa: lamentamos a sua incapacidade em reconhecer a imensa dívida que a sociologia da ciência contemporânea tem com Kuhn, e, através dele, com Polanyi; nenhum dos dois está listado na bibliografia de Gieryn.

9 Quando a URSS censurou a crítica ao Lysenkoism e este foi amplamente divulgado; a censura foi, em grande parte, para o público em geral, e não para os profissionais. 
visão. A maioria dos poderosos, e muitos dos pequenos, são cientistas normais, como Kuhn, ou seja, encanadores; e, pior, seus principais interesses são: uma vida, uma carreira; ou, no caso dos mais ambiciosos, acumular poder e prestígio, e cuidar do que é seu. Na melhor das hipóteses, todo esse pensamento é carreirista. As evidências estão à disposição, diretamente ou através de uma leitura crítica da atual sociologia da ciência, que não é assim tão crítica. Uma sociologia crítica da ciência seria aquela que sabe a diferença entre a ciência, como busca desinteressada pela verdade sobre o mundo, onde quer que ela esteja; e as muitas manifestações e simulações que se apresentam como ciência institucionalizada ou como a Voz da Ciência. Ainda assim, o milagre dos pequenos indivíduos que apresentam grandes resultados tem interessado mais de um autor. ${ }^{10}$

Temos a impressão de que os estudos da ciência, da parte de Merton e de seus alunos - Barber, Zuckerman, Ben-David, etc. - resultam de um respeito genuíno pela ciência como uma empresa e pela sua importância na aventura humana (da qual a sociologia faz parte). O trabalho de Merton apresentou algumas inovações sociais interessantes, mesmo que nem todas sejam positivas, como o Efeito Mateus, por exemplo, que é o princípio da vantagem cumulativa. A própria noção de tirar vantagem nos pareceu, em uma primeira leitura, como uma exposição da corrupção que existe no coração da ciência emergente. Merton não vê por esse lado, prefere um funcionalismo independente: é possível que seja interessante para a ciência manter essa deformidade institucional. Pode ser. Ela tem algumas funções, mas estas nada têm a ver com a ciência que busca o conhecimento. Afinal, a idéia de que aqueles com histórico melhor devem ser beneficiados é indutivista, e os filósofos sabem que Hume provou que a indução é totalmen-

10 Exemplos: William Shakespeare, "Alguns têm a grandeza lançada sobre si", Noite de Reis, Ato II, Cena V; Rudyard Kipling, "O Homem Que Queria Ser Rei", 1888; Robert Louis Stevenson, Padre Damião: Carta Aberta ao Reverendo Dr. Hyde de Honolulu, 1890. 
te, irremediavelmente inválida. Será que esse princípio é realmente o meIhor que a mão invisível da sociedade tem para oferecer à ciência? Quando os editores de periódicos rendem-se ao Efeito Mateus, não é o público que perde? Se assim for, então a função a que o efeito serve só funciona a curto prazo: a longo prazo, torna-se um obstáculo. ${ }^{11}$

Deixando para trás a seção de Gieryn sobre a ciência mertoniana, avançamos para as seções subseqüentes: o fazer ciência e a ciência como autoridade. Essas duas "linhas de investigação", isoladas por Gieryn, levantam sérias dúvidas sobre haver ou não qualquer "respeito genuíno" pela ciência, tanto por parte das ciências naturais em estudo, quanto da ciência sociológica como é praticada. Encontramos, profundamente enraizadas nessas duas linhas de investigação, os três pressupostos filosóficos que foram delineados no início deste trabalho: o respeito pela autoridade, a confusão indiscriminada das sociologias da ciência e da tecnologia, e a afirmação de que o progresso intelectual (na ciência) é sociologicamente explicável (redutível). Por trás dos três pressupostos, encontramos uma atitude que é bem diferente daquela de Merton: desmascarar ou desmistificar. Temos a forte impressão de que entre as linhas de estudo desta parte da sociologia da ciência esconde-se a vontade de desmascarar a ciência e apresentá-la como sendo apenas outra forma de trabalho, não muito diferente do trabalho de fábrica, de encanamento, de engenharia, ou mesmo de contar histórias ("narrativas", no jargão). Evidentemente, os estudos da ciência podem ser beneficiados pelo contraste com essas atividades. Mas será que os sociólogos da ciência estão atentos para perceber onde a ciência se difere dessas formas de trabalho práticas, tecnológicas?

11 O Efeito Mateus generalizado é famoso na literatura sobre práticas econômicas como discriminação estatística. Ver o artigo "Discrimination, Statistical", em International Encyclopedia of the Social Sciences, 2a. Edição, Macmillan Reference, EUA. 
Devem estar, caso contrário, não poderiam afirmar que o que fazem é sociologia da ciência. O que então eles admitem que é especial na ciência? Não são as afirmações de que esta busca a verdade, porque estas eles colocam lado a lado com a retórica persuasiva a que recorrem os cientistas. A resposta está na autoridade, suas reivindicações à autoridade, publicamente reconhecidas, a atribuição pública da autoridade; são essas as qualidades que tornam a ciência especial para esses sociólogos. Enquanto fingem estar oferecendo uma investigação imparcial, na verdade são adoradores do poder. Para ser justo, é muito difícil manter o distanciamento sociológico e, ao mesmo tempo, manter-se crítico. Mas é a falta de crítica que mantém as coisas como estão.

Vamos agora inserir um fragmento de sociologia, com uma comparação diferente. A arte é uma prática, uma forma de trabalho. Escritores, músicos, artistas plásticos, etc., todos eles trabalham naquilo que produzem. A maioria deles precisa estudar por um longo período, aprender com mestres, e trabalhar os materiais para criar suas obras. O resultado pode vir na forma de textos, gravações, e obras de arte visual. Eles expõem os trabalhos aos seus pares - os leitores da editora, comitês de exposição, proprietários de galerias, outros artistas - e, se forem bem-sucedidos, ao público em geral. O trabalho está sujeito ao julgamento de seus pares sempre que pretendem expô-lo ao público. Essas obras entram também em um mercado popular - um pouco mais tumultuado do que o mercado especializado. Os artistas podem ter grandes aspirações, como Bernard Shaw, Somerset Maugham, e Rudyard Kipling. Os três escritores foram muito bem-sucedidos com o público em geral e venderam muitas cópias; mas a reação de seus pares não foi unânime. A reputação de Kipling junto aos literatos só foi salva porque T.S. Eliot, um alto-sacerdote do modernismo literário, mudou de opinião. No século XIX, Mendelssohn e Mosheles reabilitaram o relativamente negligenciado J.S. Bach quando ousaram executar sua Missa em B Menor, não 
na catedral, mas na sala de concertos. Em nossa época, John Constable deixou as caixas de chocolate para ser reconhecido como um gênio. Não estamos negando que estes são exemplos de processos sociais. O que estamos afirmando é que o processo social tem um objetivo: o reconhecimento do mérito estético. O mérito estético, como tal, difere drasticamente do reconhecimento social do mesmo, e a prova disso está nos casos apresentados, onde os dois divergem. (Esta prova derruba também a falsa suposição de que o mérito é o reconhecimento do potencial, uma vez que o potencial e o real também são diferentes.)

O que está em discussão aqui é a diferença entre o que o etnógrafo pode descobrir se for crítico, e não acrítico. Se um artista inescrupuloso é reverenciado, cabe a um crítico relatar o fato. Mas seria hipocrisia ignorar que, subjacente à luta por honra e reputação, existe hoje um anseio por status e apreciação artística duradoura. A retórica está presente aqui, como em qualquer outro lugar. Assim é o mundo. E alguns artistas estão bastante interessados em fazer sucesso neste mundo. Nenhuma de suas atividades faz muito sentido se desconsiderarmos esse desejo. Isso se aplica a todos as formas de sucesso, incluindo o sucesso no mundo. Há maneiras mais fáceis de obter sucesso no mundo do que praticar artes. Essa dupla necessidade, de fazer sucesso no mundo e de ser um grande artista, às vezes incorpora a idéia de que o desprezo inicial por uma obra de arte é um indicativo de seu valor, que virá com o seu merecido reconhecimento. Sendo assim, a incompreensão e o sofrimento devem ser entendidos como promessas de que o melhor está por vir. E "o melhor" pode significar simplesmente reputação futura, uma construção social óbvia. Isso é verdade até certo ponto, mas não vai muito longe. $\mathrm{O}$ artista espera que com a reputação venha a ascensão ao Parnaso.

Como a arte se compara à ciência nesse sentido? Bastante, em nossa opinião. O trabalho em ciência pura - cosmologia, por exemplo - exige 
treinamento árduo, esforço intelectual intenso, alguma competitividade, e uma baixa expectativa de emprego. O que é que estimula esses indivíduos? O que temos a perder quando omitimos ou explicamos o básico, a tentativa de fazer o que é certo? A chance de encontrar as idéias que vão sobreviver ao teste dos fatos e nos levar um pouco mais perto de uma verdadeira imagem do cosmo? No entanto, ao contrário do que acontece com uma obra de arte reconhecida, a recompensa que o mercado oferece é muito pequena. Não há equivalente na ciência pura para um Picasso, amplamente recompensado. Em média, o trabalho ideal para um cosmólogo na academia paga muito menos do que uma especialização médica em cirurgia plástica. Mesmo que pareça haver uma luta pelo poder e por dinheiro para pesquisas, e mesmo que os veteranos ofereçam resistência às novas idéias, o que é que está em jogo? Eles estão todos dentro da estreita faixa do nível de vida burguês. Para chegar a ser podre de rico, você precisa encontrar algo que possa patentear ou registrar, e isso, na cosmologia, não existe. (É verdade que um cosmólogo pode vir a se tornar um ícone e, então, conquistar a fama e a fortuna. Mas é um acontecimento tão raro quanto a história do jovem desconhecido que consegue subir na escala social até se tornar um papa ou um presidente dos Estados Unidos).

Então, para continuar a comparação entre arte e ciência, o sociólogo pode facilmente entendê-las como formas diferenciadas de trabalho. Até aí, tudo bem. Tanto a arte quanto a ciência são sociais. Os meios da arte são comparáveis aos da ciência, que incluem a língua natural, a terminologia científica e a matemática. A mídia e as línguas são conjuntos de instituições sociais. É por meio dessas instituições que os artefatos são produzidos e discutidos. Ambas envolvem trabalho, seja em contextos particulares ou sociais. Ambas têm sido monopolizadas pela filosofia romântica, que idealiza os pensadores como heróis, titãs, alienados, incompreendidos, profetas desacreditados em sua época, e outras fantasias. E as duas oferecem seus 
produtos em mercados. O mercado da arte é bem diferente do mercado no qual se inserem as produções científicas, seja ele o mercado inicial, o mercado futuro, ou o mercado do público em geral. Mas, uma vez que o mercado envolve dinheiro, podemos suspeitar de que o assunto da discussão passou a ser a tecnologia ou, na melhor das hipóteses, a ciência aplicada. Não é necessário ser pedante para perceber o quanto é útil essa diferenciação. Os objetivos da tecnologia, da ciência aplicada e da ciência são diferentes; conseqüentemente, suas sociologias são diferentes.

A tecnologia é social - desde a estipulação de problemas até o licenciamento obrigatório e normas de segurança e qualidade (Jarvie 1966; Agassi 1985). Não se pode dizer o mesmo da ciência aplicada. Seus problemas nem sempre são tecnológicos. A medicina é um ótimo exemplo de ciência aplicada (e também de tecnologia). Não existe "ciência médica" pura. (O paradigma aqui é o da patologia teórica, embora o conceito de patologia teórica seja de 1959, ou posterior. ${ }^{12}$ ) O que existe, na verdade, são os diversos ramos da biologia - molecular, química e bioquímica, principalmente - e as muitas contribuições da engenharia, estatística, e assim por diante. A estrutura do DNA foi uma descoberta da biologia (molecular) pura que respondeu a seguinte pergunta: qual é a estrutura da molécula replicante? Este fragmento de ciência pura tem conseqüências da maior importância para a ciência forense, a genealogia, a compreensão de algumas doenças, e para a medicina como um todo. Planejar uma forma de aplicar a ciência pura no mundo é ciência aplicada. Como o DNA pode ser utilizado na identificação humana? Como o DNA pode ser modificado para servir a diferentes fins? Essas são questões da ciência aplicada. Os problemas tecnológicos são estipulados conforme

12 Peter Hucklenbroich, na introdução do artigo "System and disease: On the fundamental problem of theoretical pathology", em Theoretical Medicine and Bioethics, 1984, 5:307-323, descreve a patologia teórica como uma disciplina puramente intelectual e teórica. Ele calcula que a data do seu nascimento seja 1959 ou 1981. 
a necessidade de melhores métodos de identificação de criminosos. O uso do DNA como identificador pode estabelecer laços familiares, reunir toda a raça humana em uma única família, e criar relações entre todos os seres vivos da famosa árvore da vida de Darwin. Neste meio século que se passou desde a descoberta de Crick e Watson, a tecnologia vem sendo desenvolvida e refinada para possibilitar todas essas e muitas outras linhas de investigação. É possível que tanto a tecnologia quanto a ciência aplicada possam encontrar resultados que contestem a ciência pura, ou a pesquisa básica.(Observação: as aplicações da biologia molecular à teoria da evolução pertencem à ciência pura, e não à tecnologia; a tecnologia, como é encontrada em laboratórios de pesquisa, na maioria das vezes pertence à ciência pura. E assim por diante.)

É a relação lógica da contradição que está por trás de toda a ciência (Popper, 1959, §11), e a descoberta de uma contradição pode ser um efeito colateral da ciência aplicada ou da aplicação de tecnologia, bem como da pesquisa pura. Como observamos, a ciência empenhou-se em refutar veIhas idéias, especialmente aquelas pré-científicas; e, dessa forma, criou um novo problema objetivo. Qualquer leitor de Galileu sabe como ele tentou, pacientemente, mostrar que a evidência vai contra as idéias estabelecidas, incluindo aquelas que são intuitivas. Ele reuniu provas para fazer pressão intelectual sobre as idéias estabelecidas e demonstrar ao público a racionalidade das alternativas. Ele era um grande escritor e, claro, fez uso de suas incríveis habilidades retóricas e dramáticas ao apresentar o seu caso. Exemplos como esse levaram alguns sociólogos da ciência a afirmar que ciência é retórica socialmente especializada. Isso é muito vago. É óbvio que a ciência se aproveita da retórica, mas, retórica à parte, Galileu tinha um caso para apresentar, onde afirmava que algumas das idéias estabelecidas são falsas, e que idéias melhores estavam à disposição. Em contrapartida, a retórica de Kurt Gödel era tão pobre que, tão logo publicou seu trabalho 
(ilegível) clássico, pessoas com uma retórica melhor traduziram suas idéias para uma linguagem mais acessível. Se ciência e retórica fossem a mesma coisa, o crédito seria dos seus tradutores, e não dele.

A forma como tratamos o assunto, sem dúvida, será rebatida pelos céticos da sociologia da ciência como sendo autodefesa e retórica, uma tentativa de negociar com os leitores através da manipulação dos fatos, etc. Sem dúvida, são linhas de oposição impecáveis. No entanto, aplicam-se tanto aos que nos criticam quanto a nós mesmos. Cabe ao leitor decidir entre o nosso argumento e o dos nossos alvos. Mas essa decisão vai depender da sua capacidade de raciocínio ou da sua vulnerabilidade à retórica? Ou será que vai depender da sua avaliação sobre o nosso prestígio? O sociólogo trata a visão intelectual da ciência como a perspectiva estabelecida, e tenta reunir provas para mostrar que o problema está na falta de sociologia. "Não existe nada que não seja social na ciência" (Gieryn, p. 13696). A natureza é social? Sim, a natureza é uma construção retórica em nossas línguas naturais, é verdade. Uma questão melhor: A natureza é somente uma construção social em nossas línguas naturais? Continua muito vago. Por "natureza" entendemos o contexto natural para a sociedade. No entanto, para representar e discutir sobre a natureza, precisamos da sociedade e da linguagem. Isso quer dizer que a natureza não é "nada além" de representações e discussões? Alguns sociólogos são fortemente tentados por este non-sequitur. A natureza lhes parece um holograma: uma transparência criada para fins sociais. É isso mesmo, mas será que este holograma não está tentando nos mostrar alguma coisa? Para ser mais técnico, a fim de afirmar que $X$ não é nada mais do que $Y$, é necessário um contexto mais amplo, que inclui $\mathrm{X}$ e $\mathrm{Y}$. Este contexto mais amplo é a natureza. Se a natureza não fosse nada mais do que um holograma, os cientistas das ciências naturais não poderiam mais explorá-la. E não haveria nenhuma pesquisa em ciências naturais para impedir isso, 
nenhuma sociologia da ciência, nenhuma retórica. Neste ponto, precisamos começar a oferecer nossas próprias sugestões para o esqueleto de uma sociologia crítica da ciência.

\section{Nossas Metas}

Por sociologia da ciência entendemos uma sociologia das instituições científicas, desde a Royal Society de Londres, fundada (pelo menos duas vezes) em 1660-63, até os dias de hoje. Uma sociologia geral da ciência tem que ser baseada na sociologia de um modo geral, na forma como trata as instituições, e no papel que atribui à ciência na sociedade (explícito ou tácito, como costuma ser nas ciências sociais). Entendemos que a sociologia geral de hoje não compreende a ciência, e que são necessários estudos sociológicos mais específicos para tratá-la.

Qual é o problema? Em primeiro lugar estão os três pressupostos filosóficos que estamos discutindo. Segundo, será que podemos compensar a precariedade e a parcialidade dos trabalhos clássicos da sociologia da ciência? Em terceiro lugar, a questão principal é: até que ponto as instituições da ciência são instituições sociais típicas, até que ponto o fato de serem instituições da ciência faz com que sejam significativamente diferentes? (Significativas para quê?)

Sugerimos como função principal das instituições sociais a coordenação. ${ }^{13}$ Antes do desenvolvimento da linguagem, provavelmente já havia instituições, ou alguma coisa que possamos chamar de instituição (talvez por mera extensão): elas devem ter crescido juntas. Todas as teorias sobre o surgimento da linguagem sugerem um esforço coletivo, uma forma de melhorar a coordenação. A invenção da linguagem foi, sem dúvida, um

13 J. Agassi, "Methodological Individualism", British Journal of Sociology 11, 1960:244-70; reeditado em J. Agassi e I.C. Jarvie, Rationality: The Critical View, Dordrecht: Kluwer, 1987. 
grande avanço na capacidade humana de coordenar, e veio a se tornar uma importante instituição social e universal. Como afirmam Goody e Watt (1963), a invenção, subseqüente, da linguagem escrita foi um salto quântiCo, afetou a memória humana e tornou possível a idéia de lei, e também a idéia de que, em certo sentido, as afirmações têm uma existência própria. Sem a linguagem escrita, praticamente não há ciência. Para colocar de outra forma: a empresa que conhecemos como ciência é muito diferente das empresas cognitivas que existem nas sociedades sem escrita.

Concordamos que uma sociologia geral da ciência deve começar pela linguagem. Embora a linguagem comum seja de uso constante nas relações das ciências naturais - na realização de pesquisas e na divulgação dos seus resultados, incluindo o ensino da ciência - sabe-se que o esoterismo da ciência é devido, em parte, à sua linguagem (ou linguagens) especializada, a qual deve ser dominada antes que se possa empreender qualquer esforço para contribuir com a ciência. O desenvolvimento das línguas de especialidade foi impulsionado por várias considerações, na sua maioria legítimas: quanto maior o conhecimento prévio envolvido em uma discussão, maior será o número de termos a que se faz referência, termos técnicos cuja utilização está condicionada à aquisição de conhecimento. O efeito funcional dos termos técnicos, no entanto, foi a exclusão: aqueles que não estão familiarizados com o conhecimento prévio necessário a uma discussão, estão excluídos. C.P. Snow apresentou o problema na Rede Lecture de 1959. ${ }^{14}$ Para ele, a cultura da ciência seria uma subcategoria especializada da cultura geral, que às vezes faz uso da linguagem comum, mas que se vê obrigada a criar e utilizar linguagens

14 C.P. Snow, "The Two Cultures" (As Duas Culturas), 1959, reeditado em 1993. Snow sugeriu que o ensino da terminologia técnica em escolas poderia preencher as lacunas que existem entre os cientistas e o público leigo; para isso, sugeriu emular o sistema educacional soviético. Dessa forma, ficou claro não só o seu desconhecimento acerca do sistema de ensino soviético, mas também a sua falta de compreensão no que diz respeito à aquisição de termos técnicos. 
técnicas na maior parte do tempo. Uma vez que estas linguagens técnicas não foram ensinadas a todos os alunos, e não são fáceis de dominar, o resultado foi a criação de muros em torno da ciência. Esses muros sociais abstratos precederam as instalações cercadas por arame farpado, seguranças e todo o aparato que se tornou comum em campi científicos desde a Segunda Guerra Mundial.

Os antropólogos sociais costumavam ensinar a seus alunos que o domínio da língua local era uma condição sine qua non para o êxito no trabalho de campo. Não se pode dizer o mesmo dos sociólogos da ciência que estudam a ciência de laboratório. Eles chegam com a linguagem comum e aprendem a linguagem científica do laboratório na medida exata para acompanhar as interações sociais. Eles são observadores, e não participantes. Alguns deles, como Harry Collins, tentam aprender a linguagem científica para poder acompanhá-la, mas não para criticar ou intervir. David Bloor, sem dúvida, foi beneficiado pela sua formação em matemática, mesmo que os estudos de laboratório não sejam o seu métier. Mas a maioria, como Garfinkel, Knorr-Cetina, Latour e Woolgar, e Lynch, fazem apenas o mínimo. Embora sigam os métodos antropológicos, até certo ponto, eles também adotam, e valorizam, a "distância analítica", o papel do estranho, o "relativismo metodológico" que supostamente lhes mantêm alheios às questões científicas estudadas no laboratório. Eles vêem as práticas de trabalho e de discurso como interações sociais voltadas somente para fins sociais (persuasão, poder, dinheiro para pesquisas, prestígio profissional). A premissa parece ser a de que em uma interação social tudo o que está em jogo são fins sociais, poder, dinheiro, status, coisas que podem ser alcançadas através da persuasão. Qual é o argumento mais convincente? Não há resposta. Sendo assim, nem a lógica e nem a linguagem apóiam a sua posição. As atividades sociais muitas vezes têm fins não-sociais, tais como a reprodução biológica ou a construção de um abrigo. Reprodução e abrigo têm aspectos sociais, mas isso não significa que sejam sociais e nada mais. Ou, caso alguém afirme que o são, então 
tudo é social, e nós estamos atolados em um solipsismo sociológico. A linguagem, da mesma forma, também é utilizada para fins não-lingüísticos - descrever, expressar, ou argumentar sobre uma ou outra coisa. Equiparar toda e qualquer coisa com outro objeto lingüístico é cair no idealismo lingüístico. Para alguns filósofos e sociólogos, essa posição parece óbvia e correta. Para nós, parece obviamente incoerente.

Os muros impostos pela linguagem técnico-científica cercam os primeiros dois mercados que foram apresentados, o mercado especializado inicial e o mercado futuro, onde os resultados iniciais são recebidos por seus pares. O mercado público é diferente: as idéias científicas são oferecidas com certa desconfiança em relação aos outros mercados. Uma vez que esses mercados são relativamente fechados, o gesto funciona como um "confiem em nós". Quando alguém diz: "confie em mim", durante uma discussão, dispara um alarme. Por que não explicar? É muito técnico? Então, que seja simplificado. É muito difícil? Existe alguma idéia, algum conjunto de evidências que não possa ser explicado às pessoas que precisam desse conhecimento? Ainda assim, é possível tentar. Basta pensar nas mudanças que ocorreram na prática médica na última geração. Muitos de nós ainda lembram de quando os médicos eram ensinados a se comportarem como deuses, e a nos fazer pensar em sua experiência e tecnologia como uma varinha mágica: o paciente deveria deixá-los agitar a varinha e ser grato se o resultado fosse positivo. Essa atitude foi incutida nos estudantes de medicina, e até certo ponto ainda é. Havia ainda uma instituição de compensação conhecida como segunda opinião, que levava em conta a falibilidade e era invocada sempre que se tratava de algo importante. Esta também enfrentou resistência.

O clima melhorou um pouco, o céu está mais claro. Hoje, as seguradoras responsáveis pelos planos de saúde estão dispostas a pagar por uma segunda opinião. Algumas escolas de medicina ensinam que o maior especialista nos males de um paciente é o próprio paciente. Ele acompanha o caso minuto a minuto, e vivencia diretamente a terapia; o paciente é o 
único fator de ligação entre os diferentes médicos, enfermeiros, técnicos de laboratório e demais profissionais empregados pelas novas instituições voltadas para o paciente. É com ele que os profissionais da saúde devem discutir os detalhes do caso, o que já se sabe, o que ainda não se sabe, e o que mostram as pesquisas sobre os diferentes tipos de terapia. Esta mudança está ocorrendo em uma profissão legalmente regulamentada que tem muito a ganhar com uma postura hermética e autoritária. ${ }^{15} \mathrm{~A}$ organização, relativamente clara, da profissão faz com que esta se torne mais flexível às reformas. Tanto na formação dos candidatos à profissão, quanto nos mecanismos institucionais da prática, é possível empreender uma reforma e acompanhar o seu desenvolvimento. Uma questão pertinente: de que forma e até que ponto a divulgação de informações médicas na Internet vai influenciar este processo.

Gieryn refere-se à ciência como uma profissão (Gieryn, p. 13697, por exemplo), e também a compara com o trabalho do encanador que realiza "tarefas duplas". Sua linguagem demonstra uma tendência ao exagero, assim como as suas referências à necessidade que a sociedade tem de "conhecimento certificado" (Gieryn, p. 13693). Essas comparações são distorções e exageros, e estão na direção (filosófica) errada. A ciência não deve ser tratada como uma profissão. ${ }^{16} \mathrm{~A}$ desorganização da ciência é uma característica que funciona como incentivo à livre investigação. Os amadores, curiosos, diletantes, excêntricos, etc., não estão totalmente excluídos. O cumprimento de tarefas que estão muito longe de ser "factíveis" é característico da ciência e vice-versa, e está mais próximo

15 Isso não quer dizer que seja do interesse dos médicos cultivar essa imagem do médico infalível, embora muitos deles pensem dessa forma. Ver Nathaniel Laor e J. Agassi, Diagnosis: Philosophical and Medical Perspectives, Dordrecht: Kluwer, 1990.

16 A revolução científica estabeleceu que a ciência é um empreendimento amador, e os esforços pela sua profissionalização começaram em 1830 e foram concluídos somente após a Segunda Guerra Mundial. Ver abaixo. Ver também Dorothy Stimson, Scientists and Amateurs: A History of the Royal Society. New York: Henry Schuman, 1948. Nem mesmo Michael Polanyi e Thomas S. Kuhn reconhecem esse fato, embora esteja presente em sua sociologia. 
da direção (filosófica) certa. O problema com o trabalho de fábrica e de encanador, como análogos para a ciência, é que o tipo de imaginação que este trabalho requer tem pouca ou nenhuma semelhança com o tipo de imaginação que é necessário para alterar a nossa visão das coisas. Quanto à necessidade funcional que a sociedade tem de conhecimento certificado: o que a sociedade faz quando não há conhecimento certificado, quando este falha, ou quando perde a sua certificação? A resposta é simples: ela funciona sem conhecimento certificado. Na verdade, todos os certificados de conhecimento são falsos, independente da quantidade de garantias sociais que apresentam. O "conhecimento certificado" ou "certificado de especialização" é um mito, a necessidade de ter conhecimento certificado é um mito. (Não é o caso da competência técnica certificada.) Nós queremos ver os sociólogos separarem a fato do mito dos outros fatos sociais. Mas a sociologia da ciência ignora a diferença entre os dois, o que lhe confere o status de mito.

"Ciência" é uma expressão bastante flexível (que data da década de 1850). Seu cognato alemão "Wissenschaft" é ainda mais flexível (tanto que existe um termo como "ciência dogmática", para denotar teologia e lei). É por isso que as instituições e funções que precisam ser catalogadas na sociologia básica da ciência são tão amplas e difíceis de demarcar. A educação científica começa no ensino médio e na graduação. Aqueles que não têm essa base não podem ser considerados cientistas, infelizmente. Os cientistas da Revolução Científica muitas vezes não tinham formação científica, eram autodidatas. Michael Faraday e Thomas Alva Edison servem como exemplo. Francis Upton, que foi assistente de Edison, tinha Mestrado. Hoje, a ciência é mais formal e exige um Doutorado. Esse credenciamento é recente, não é necessário, e pode ser tanto uma barreira quanto uma qualificação. Michael Polanyi afirma que as barreiras são necessárias para impedir a entrada de excêntricos e curiosos. Dado 
que, de Kepler a Schrödinger, Pauli, Dirac e Pauling, muitos cientistas do mais alto nível também foram excêntricos ou curiosos de uma forma ou de outra, é difícil concordar com Polanyi.

\section{Formas elementares da vida científica}

Vamos dar um passo para trás. Para deixar as coisas mais simples, vamos considerar a ciência a partir da Revolução Científica. Começaremos, então, pelos indivíduos que estavam fazendo ciência, mas apenas no sentido de que o resultado ("ciência") foi uma conseqüência não-intencional de suas atividades, as quais poderiam muito bem ser descritas como experimentação, curiosidade, observação, especulação, discussão (muitas vezes por carta), e principalmente diversão. Podemos dizer que a ciência foi uma conseqüência não-intencional dessas pesquisas e discussões informais, e que floresceu antes mesmo de ter um nome; ela floresceu sob seu primeiro nome: "filosofia natural"; e, mais tarde, quando optaram pelo nome "ciência", o termo mudou o sentido para acomodar a revolução na física, no início do século XX. O sociólogo da ciência de hoje pode não querer começar por essas formas elementares da vida científica. Afinal, somos constantemente lembrados de que, segundo Derek J. de Solla Price, a maior parte das pessoas que já foram consideradas cientistas estão vivas hoje, e "devemos ter dois cientistas para cada homem, muIher, criança e cão na população". ${ }^{17}$ Mesmo que não se trate de um uso equivocado da palavra "cientista", isso dificilmente explica por que tantos sociólogos e historiadores da ciência produzem estudos de caso históricos, especialmente nos séculos XVII e XVIII. ${ }^{18} \mathrm{~A}$ explicação para isso, que

17 Derek J. de Solla Price, Little Science, Big Science. New York: Columbia University Press, 1965, p. 19.

18 É bem possível que os sociólogos da ciência não sejam capazes de compreender textos de "ciência dura" dos períodos posteriores. 
derruba o argumento que toma como norma a maioria das pessoas vivas hoje, está no fato de que a sociologia da ciência está mais interessada nas instituições. Só porque as primeiras instituições eram informais, e foram as instituições informais que criaram a primeira instituição formal - a Royal Society de Londres e seus imitadores - não significa que elas estejam sociologicamente ultrapassadas. Pelo contrário, a longevidade das instituições é bem conhecida. Às vezes, instituições que se formaram, mesmo que abaixo do radar, mostram-se mais duradouras do que instituições que foram planejadas. Na excelente dramatização da descoberta de Crick e Watson, pela $\mathrm{BBC}$, os produtores se esforçaram para mostrar que os grandes pesquisadores eram também experimentadores, ecléticos, curiosos, entusiastas, e assim por diante. ${ }^{19}$ Mesmo nos dias de hoje, uma das instituições características da ciência de laboratório é o grupo. Este pode ter aspectos formais (todos aqueles que foram pagos para trabalhar em um determinado laboratório, em um determinado projeto), mas tem também seus aspectos informais, como uma rede social flexível no estilo Simmel. Uma vez que há interação nas margens com pessoas de fora do grupo e com outros grupos, há uma rede informal desenvolvida com outros pesquisadores de todo o mundo, conversas de bebedouro, encontros em reuniões, dicas, enfim, nada que possa ser facilmente mapeado. São como arranjos sociais, complexos e flutuantes, em um grupo de pessoas que têm algo em comum e que estão ansiosas para falar sobre isso. Em alguns grupos, é comum ocorrerem experimentações, especulações, brainstorming. Esta é a sociologia da ciência no ponto zero. Uma das representações favoritas do cientista

19 Estamos nos referindo ao filme de 1987, dirigido por Mick Jackson, com Jeff Goldblum como Watson, Tim Piggott-Smith como Crick, Alan Howard como Maurice Wilkins, e Juliet Stevenson como Rosalind Franklin. Também é conhecido como "Double Helix", "The Race for the Double Helix", e "Life Story". Outra excelente descrição (crítica) da ciência é a série "The Voyage of Charles Darwin" (1978), da BBC, que procurou reproduzir os diálogos entre Darwin e Charles Lyell, o Capitão Fitzroy, as evidências geológicas e fósseis, e o próprio Darwin. 
do futuro na mídia de massa é a do garoto que faz experimentos em uma espécie de oficina-laboratório como um jovem Edison. Será que os meios de comunicação estão muito longe da verdade?

Para apresentar o assunto com um pouco mais de formalidade, na sua pré-história e início da história, a ciência surgiu no seio da sociedade civil e das associações que a tornaram possível. Mas, quando surgem as instituições formais, a sociedade civil não perde o seu papel. Existem, nas instituições científicas, associações informais da sociedade civil, particularmente importantes quando se trata de pular a cerca das instituições para outras associações, formais e informais.

\section{O Crescimento das Instituições}

Com os padrões institucionais da atividade científica para a produção de ciência, surgem as instituições científicas formais e a educação científica. A educação científica começa com a matemática. Era essa a formação de Galileu. Era essa a formação de Descartes. Foi onde surgiram as inovações de Newton e Leibniz. Em Pisa, onde Galileu estudou, a matemática já fazia parte do currículo universitário. Os primeiros laboratórios modernos ${ }^{20}$ eram particulares: na corte de diletantes ricos que queriam experimentar; nos estudos daqueles que dispunham de espaço e know-how. Por mais de dois séculos, o Observatório Real de Greenwich empregou um astrônomo e não mais do que cinco assistentes - os únicos cientistas profissionais na Grã-Bretanha até 1800, quando foi fundado o Royal Institution da Grã-Bretanha, com o intuito de realizar pesquisas e divulgar seus resultados, independente da academia e da Royal Society. O desenvolvimento do laboratório como instituição foi uma conseqüência

20 Antes disso, existiam laboratórios alquimistas, médicos e mineralógicos, sem status científico, pelos padrões da Royal Society de Londres. 
não-intencional do trabalho de curiosos que queriam um lugar para experimentar e manter seus equipamentos. Seguindo o modelo da Royal Society, mesmo antes de ter sido profissionalizada, surgiram as mais diversas instituições, reunindo matemáticos, estatísticos, físicos, geógrafos e antropólogos, somente na Grã-Bretanha. O primeiro laboratório científico em uma universidade inglesa foi o Laboratório Cavendish, em Cambridge. É sociologicamente importante ressaltar tudo isso porque, em uma perspectiva histórica, a associação da ciência com as universidades e as grandes empresas é recente e anômala, não é natural ou predestinada. Quanto aos militares, sabemos pela primeira monografia de Merton (1937) que a associação é de longa data, o que não quer dizer que a intrusão dos militares durante a Segunda Guerra Mundial e a Guerra Fria foi bem recebida. Merton estava certo quando disse que o comunismo foi fundamental para o ethos da ciência. Assim, o investimento militar, vinculado ao sigilo e ao isolamento, foi e ainda é, obviamente, um obstáculo para o surgimento de uma comunidade comunista de cientistas.

Apenas uma pequena modificação se faz necessária quando mudamos o foco para o crescimento dos laboratórios no setor da indústria, principalmente no da indústria química da Europa Ocidental, em meados do século XIX. O desenvolvimento dos produtos, e a questão da ampliação da bancada do laboratório para se obter uma capacidade industrial foram incentivos óbvios para a criação de laboratórios próprios. A necessidade de incluir em suas atividades a exploração de possíveis novos produtos foi imposição da indústria, apesar de envolver ciência, ciência aplicada e tecnologia de base científica.

E, por último, a academia; última, mas não menos importante. A academia só entrou no vagão da ciência em meados do século XIX (e, em alguns países, somente no final do século XIX). A partir daí, há um consenso sobre a importância do trabalho em laboratório para o ensino da ciência, 
uma expectativa quanto à carreira científica, órgãos de publicação, e um acordo para modificar as divisões do conhecimento, que até então seguiam o modelo de Aristóteles (um exemplo da longevidade das instituições), de modo a criar departamentos responsáveis por determinadas áreas da investigação científica. Na sua forma mais simples, a divisão se resumia em física, química e biologia, conforme está expresso na fundação de universidades técnicas e escolas de engenharia nas universidades mais antigas dos Estados Unidos e da Europa. O leitor está convidado a visitar o site de sua própria universidade, ou de alguma outra, e contar o número de divisões e subdivisões de cada uma dessas três áreas que podem ser encontradas hoje em dia. Pode também refletir sobre as variações de nomes e os diferentes quadros organizacionais de cada universidade.

Essa fissão departamental é sociologicamente subexplorada. Cada departamento que se divide, a princípio, já comportava as atividades que agora vão agora ser repartidas sob a sua égide. O que motiva essas divisões? Autonomia é a resposta mais óbvia. Mesmo assim, há limites, e o sociólogo da ciência só tem a ganhar ao investigar os obstáculos que foram impostos à autonomia na estrutura anterior. Será que é tão simples como a resistência ao novo, incluindo novos desafios às fronteiras? E por que, tão logo é feita a divisão, os departamentos recém-criados procuram elaborar limites para si mesmos, os quais se esforçam para policiar? Isto é, por que eles reproduzem a resistência institucional à autonomia, se o objetivo da divisão era superar essa resistência? Este é outro caso do que se entende por persistência de padrões institucionais por longos períodos de tempo. Por que os limites, e o policiamento dos mesmos, estão presentes na vida acadêmica, uma vez que não foram herdados dos experimentadores, diletantes, curiosos, observadores, e especuladores a partir dos quais a ciência acadêmica se desenvolveu? Por que o currículo é um campo de batalha em quase todos os departamentos universitários? Por que as universidades 
presumem que podem garantir que um indivíduo com um diploma de tal curso terá o domínio de tal área? É comum as profissões administrarem seus próprios testes de admissão, e consideram que tornar público o conteúdo do teste já é o bastante. É interessante observar o funcionamento das universidades de língua alemã do século XIX e do início do século XX. O aluno, uma vez matriculado, poderia migrar de curso para curso, em qualquer parte da universidade, e de uma universidade para outra; estudando aquilo que lhe interessasse. Para ser graduado, precisava optar por uma área e estar preparado para os exames dessa área. Esses alunos poderiam sair da universidade com diplomas híbridos, com as mais inusitadas combinações. (Obviamente, havia exceções. Direito e medicina, principalmente as especializações médicas, são as mais óbvias.) Não se sabe ao certo se as ciências ou os estudantes foram prejudicados por essa prática.

Para responder as perguntas do parágrafo anterior, os sociólogos precisam levar em consideração as diferenças intelectuais. Freqüentemente, as divisões são promovidas por disputas sobre o mundo e sobre como as pesquisas devem ser conduzidas. Na ciência, há escolas de pensamento que tratam de questões intelectuais como "quais são os problemas mais interessantes?", "quais são as linhas de pesquisa mais promissoras?", "quais são os resultados dessa ou daquela abordagem?", e assim por diante. Essas escolas, por vezes, alcançam grande longevidade, e estão em uma luta constante quanto à natureza das coisas. Investigar a natureza das coisas é uma forma de cooperação amigável-hostil, para usar a expressão de Popper; e, naturalmente, pode levar a disputas pelo poder, que é usado para desencorajar, subfinanciar, subpromover, e depreciar as outras escolas. Negar que status e poder estão entre os objetivos do exercício é uma utopia muito ingênua; mas considerar status e poder como sendo os únicos objetivos é ainda pior: é um reducionismo ingênuo, o tipo de coisa que antes era chamado de ponto de vista do observador de Marte. (A pró- 
pria sociologia serve de exemplo. O que distingue o Journal of Classical Sociology, por exemplo, dos outros periódicos? Pode-se dizer que ele leva os clássicos a sério; pode-se dizer também que ele incentiva a investigação sociológica que nega a versão relativista do construtivismo social. ${ }^{21}$ )

Finalmente, chegamos à era moderna, a era de Kuhn, o defensor da nova rotinização burocrática da ciência, muitas vezes tomada como norma na sociologia da ciência contemporânea. Kuhn dividiu a vida de uma ciência em dois ciclos, o normal e o excepcional. A ciência normal consiste em trabalho racionalmente rotinizado na base de um paradigma estabelecido. A ciência excepcional surge quando o paradigma estabelecido começa a apresentar problemas, quando suas anomalias e remendos tornam as pesquisas difíceis ou improdutivas. Segue-se um período de luta, tanto para renová-lo quanto para descartá-lo e buscar um novo paradigma. Kuhn vê esse período revolucionário não como um período da ciência, mas como um interregno: a pesquisa é desorganizada e seu status desconhecido. (A ascensão dos curiosos e dos excêntricos!) A ciência só recomeça quando um novo paradigma está estabelecido, amplamente aceito, e desempenha o papel de uma nova base para a pesquisa recémrotinizada. Não sabemos como resolver a contradição que existe entre "ciência normal" e "ciência revolucionária", e o fato de que a ciência revolucionária não é ciência. O que sabemos é que a sociologia da ciência, elevada a um patamar impressionante, absorveu esta imagem completamente, apesar do fato de que qualquer observação de qualquer detalhe histórico deveria levar um seguidor de Kuhn a concluir que a ciência observada está em um interregno. Gieryn não menciona o assunto porque, supomos, assume que se trata de "deep background". Presumimos que está

21 Uma dos textos relativistas mais extremos com que já nos deparamos (Edwards et al, 1995), publicado, inusitadamente, no periódico History of the Human Sciences, apesar de não ser histórico, mas construtivista e filosófico. 
profundamente enterrado porque Kuhn, principalmente, considera as ciências sociais pré-paradigmáticas e, portanto, pré-ciência, ou, na melhor das hipóteses, protociência. $\mathrm{O}$ contra-argumento de que são uma nova espécie, multiparadigmática, não deu frutos. Multiparadigma implica em muitos paradigmas, o que significa nenhum no sistema de Kuhn, onde deve haver consenso sobre um modelo único para tornar uma disciplina científica. Ao admitir que sua teoria é sociológica e que as ciências sociais são multiparadigmáticas, Kuhn está admitindo a derrota. Sua inspiração, portanto, é também um embaraço.

Segundo Kuhn, a ciência normal é mais eficiente. A sua teoria parece mais atraente, uma vez que oferece uma visão da ciência onde a experimentação, a curiosidade e a especulação diletante são minimizadas. A ciência está racionalmente rotinizada e pode ser comparada com uma fábrica ou um encanamento; o que permite a assimilação da ciência pela sociologia do trabalho. Mas tanto o trabalho de fábrica quanto o de encanamento são tecnológicos. A tendência, portanto, é ver a ciência como uma forma de trabalho tecnológico ${ }^{22}$. Os cientistas seriam todos como Edison, Eastman, Bell, Land, etc., trabalhando para criar um produto final tecnológico. A cosmologia é, naturalmente, um desafio, uma vez que não cria nada tangível, lida confortavelmente com vários paradigmas antagônicos, e se mostra poderosa. Se observarmos a tentativa, por parte dos etnometodologistas Garfinkel et al. (1981), de reduzir as atividades dos astrônomos a um trabalho rotinizado (sobre o pulsar), podemos perceber pelas notas de laboratório, pelas conversas gravadas, pelas discussões quanto ao que os instrumentos estão registrando, que tudo isso é usado para mostrar que eles produzem (ou seja, fazem) um modelo do pulsar, como os atores produzem um modelo da sociedade em suas interações. Sendo assim, não há um "objeto de Galileu" chamado "pulsar" descoberto nos Céus. O que existe

22 De fato, assim como os sociólogos do trabalho se importam com a qualidade de vida no trabalho, e protestam contra a rotinização excessiva; alguns deles chegaram à conclusão de que, se Kuhn está certo, a qualidade de vida nas pesquisas também precisa melhorar. 
são práticas sociais arcanas de instrumentação, processamento e discussão que levam ao discurso que, erroneamente, sugere ser esse o caso. Os atores produzem uma peça chamada ciência, e a peça conta uma história. ${ }^{23} \mathrm{~A}$ história não é real, somente a atuação e a produção são reais. Como neste modelo os restaurantes não produzem comida, mas uma história de alimentos, podemos dizer que o solipsista sociológico é quem está sendo iludido. $\mathrm{Ou}$ talvez não exista nenhuma sociologia da ciência, nem etnometodologia, o que existe é apenas um faz de conta.

A etnometodologia, para ser justo com a sociologia, é apenas uma escola ou paradigma para a sociologia da ciência. Como todos os paradigmas, ela ignora os cosmólogos do lápis e papel ${ }^{24}$, preferindo estudar aqueles que podem ser encontrados "trabalhando", em um "local de trabalho". Mas isso é geral na sociologia da ciência. Quanto mais se distanciam do trabaIho intelectual, mais confiantes se sentem. Quanto mais se concentram no discurso, e menos nas idéias, mais surpreendentes são as suas conclusões. A etnometodologia, acima de tudo, é abertamente idealista; tanto que foi rotulada como uma versão do solipsismo: "solipsismo sociológico" (o mundo, os fatos, o pulsar, são sonhos sociais). Esses pesquisadores são como Christine Ladd-Franklin, a famosa solipsista que escreveu a Bertrand Russell para dizer que não entendia por que a sua posição não era adotada por todos $^{25}$. Nem todos os sociólogos da ciência são idealistas com tendências

23 R.G. Collingwood usava esta teoria para explicar a magia, uma vez que estava relutante em aceitá-la sem reservas, recusando-se a ver seus praticantes como irracionais. É melhor ter uma visão mais flexível da racionalidade, uma que atribui alguma racionalidade à magia e uma maior racionalidade à ciência (Jarvie e Agassi, 1967).

24 Uma piada famosa atribui à esposa de Einstein a afirmação de que um pesquisador só precisa de um lápis e de um envelope usado, onde possa escrever alguma coisa na parte de trás. 25 "Quanto ao solipsismo, deve-se dizer, em primeiro lugar, que é psicologicamente impossível acreditar; e, de fato, é rejeitado até mesmo por aqueles que dizem aceitá-lo. Certa vez recebi uma carta de uma eminente lógica, Sra. Christine Ladd Franklin, dizendo-se solipsista, e que estava surpresa por não haver outros. Vindo de uma lógica e uma solipsista, sua surpresa me surpreendeu" (Bertrand Russell, Human Knowledge: Its Scope and Limits, Londres: George Allen \& Unwin, 1948, p. 180, traduzido livrem 
solipsistas. Mas o que foi dito neste trabalho é suficiente para mostrar que há uma aceitação generalizada - seja ela séria ou não - da filosofia barata e acrítica. O que é engraçado, porque acima de tudo, eles querem ser críticos, radicais, céticos, desmistificadores. Em vez disso, aceitam todos os tipos de mitos, ilusões, delírios, erros, non-sequiturs, e rejeição aos fatos. Fazer isso é o mesmo que endossar, ou reendossar, o status quo. Este é sem dúvida um projeto contra-lluminista; mas, como é involuntário, estamos convidando seus praticantes a retornarem à razão.

\section{Towards a general Sociology of science}

\section{Abstract}

In this critical and constructive paper we argue that much received sociology of science is skewed by a presupposed idealist philosophy, one that encourages an uncritical attitude towards the supposed facts of the matter. We propose a critical sociology of science that (1) unfuses science, applied science, and technology - (2) emphasizes fallibility in science and the sociology of science - and that (3) deconstructs all claims to authority.

Constructively, we sketch the elements of a sociology of science that comprehends the elementary forms of the scientific life as well as contemporary bureaucratized and militarized "normal" science.

Keywords: Merton. Sociology of science. Strong programme. Authority. Institutions. Gieryn. Language. Objective knowledge.

\section{Referências}

AGASSI, Joseph. Methodological individualism. British Journal of Sociology, 11, p. 244-70, 1960.

AGASSI, Joseph. Technology. Dordrecht: D. Reidel, 1985. 
EDWARDS, Derek; ASHMORE, Malcolm; POTTER, Jonathan. Death and furniture: the rhetoric, politics and theology of bottom line arguments against relativism. History of the Human Sciences, 8(2), p. 25-49, 1995.

GARFINKEL, Harold; LYNCH, Michael; LIVINGSTON, Eric. The work of a discovering science constructed with materials from the optically discovered pulsar. Philosophy of the Social Sciences, 11(2), p. 131-58, 1981.

GELLNER, Ernest. Cause and Meaning in the Social Sciences. London: Routledge, 1973.

GIERYN, T. F. Sociology of Science. In: International Encyclopedia of the Social \& Behavioral Sciences, p. 13692-13698, 2001.

GOODY, Jack; WATT, Ian. The consequences of literacy. In: Comparative studies in society and history, 5(3), p. 304-45, 1963.

JARVIE, I. C. The social character of technological problems. In: Technology and Culture, Vol. 7, July, pp. 384-90, 1966. Reprinted in Carl Mitcham and Robert Mackey, eds., Philosophy and Technology, New York: Free Press, 1972, pp. 5053; also in F. Rapp, ed., Contributions to a Philosophy of Technology: Studies in the Structure of Thinking in the Technological Sciences (Theory and Decision Library 5), Dordrecht: D. Reidel, 1974, pp. 86-92.

JARVIE, I. C. ; Agassi, Joseph. The problem of the rationality of magic. In: British Journal of Sociology 18(1), p. 55-74

LAUDAN, Rachel. Review of Oreskes 1999. In: Philosophy of Science 67(2), p. 343-45, 2000.

MERTON, Robert K. Science, Technology and Society in Seventeenth Century England, Osiris, 4(2), 1938.

ORESKES, Naomi. The Rejection of Continental Drift. In: Theory and Method in American Earth Science. Oxford: Oxford University Press, 1999.

ORESKES, Naomi (ed). Plate Tectonics. In: An Insider's History of the Modern Theory of the Earth. Boulder, CO: Westview, 2001.

POPPER, K. R. The Logic of Scientific Discovery. London: Hutchinson, 1959.

SNOW, C. P. The Two Cultures and the Scientific Revolution. Cambridge: Cambridge University Press, 1959.

Recebido: $15 / 09 / 2010$

Aceite final: 30/09/2010 